\title{
Remuneration Guidelines for
}

\section{Strength and Conditioning Coaches \\ within Universities in the United}

Kingdom: International Universities

Strength and Conditioning

Association (IUSCA) Position

Statement

\section{Andrew Langford, MSc ASCC ${ }^{1}$, Aden Flannagan, MSc ASCC ${ }^{1,2}$, Stephen P. Bird, PhD, CSCS RSSC ${ }^{\star} E^{1,3}$}

${ }^{1}$ International Universities Strength and Conditioning Association, London, UK, ${ }^{2}$ Leicester City FC Women,

Leicestershire, UK, ${ }^{3}$ University of Southern Queensland, QLD Austrailia.

\section{INTRODUCTION}

The remuneration of strength and conditioning (S\&C) coaches corresponding to the professional services provided across the high school, collegiate and professional sector, ${ }^{1}$ has received increased attention in recent times. This appears to be a highly contentious topic regarding the governance of industry awards (National minimum wage) and remuneration. ${ }^{2-5} \quad$ Currently, only the Australian Strength and Conditioning Association (ASCA) ${ }^{7}$ provide remuneration guidelines, with the National Strength and Conditioning Association (NSCA), ${ }^{5}$ and the United Kingdom Strength and Conditioning Association (UKSCA $)^{6}$ providing professional standards for their respective sectors. While professional bodies have no legal power to enforce remuneration guidelines, ${ }^{4}$ they do provide key recommendations for consideration when entering an employment relationship. Despite this, the issue of appropriate remuneration is exemplified by recent examples of such jobs being undervalued throughout the industry. ${ }^{3}$ In relation to the remuneration of $S \& C$ coaches within Universities, the International Universities Strength and Conditioning Association (IUSCA) has recently carried out extensive research across UK Universities and found that there is inconsistent grading regarding the role of a S\&C coach. ${ }^{8}$ Therefore, the IUSCA has produced this Position Statement to assist Human Resources (HR) departments in developing Job Descriptions, Role Profiles, and associated remuneration packages appropriate to the provision of S\&C support within university settings. Such guidelines provide a point of reference to further enhance professional industry standards for S\&C coaches employed within UK Universities.

\section{IUSCA STRENGTH AND CONDITIONING COACH GRADING}

In the professional sporting environment, the IUSCA understands that laws of basic economics and supply-and-demand will influence wages, and the value of an S\&C coach may therefore be impacted. ${ }^{9}$ This makes it challenging for guidelines to be introduced and adhered to in an open market. However, while the IUSCA understands free market economies and appreciates that competition will often dictate value, circumstances within UK Universities are different, and warrant fair grading and remuneration. As UK Universities adhere to a standard grading scale using the Higher Education 
Table 1. IUSCA Strength and Conditioning Coach Grading

\begin{tabular}{|c|c|c|}
\hline Job Title & HERA Points & $\begin{array}{c}\text { Salary (approx. based on cur- } \\
\text { rent scales 2020) }\end{array}$ \\
\hline Strength and Conditioning Intern & $\mathrm{n} / \mathrm{a}-$ Intern \\
\hline $\begin{array}{c}\text { Strength and Conditioning } \\
\text { Graduate Intern }\end{array}$ & $\mathrm{n} / \mathrm{a}-$ Graduate Intern & $\begin{array}{c}\text { University Graduate Intern salary } \\
-£ 17,500-£ 20,500\end{array}$ \\
\hline $\begin{array}{c}\text { Assistant Strength and } \\
\text { Conditioning Coach }\end{array}$ & $\begin{array}{c}\text { Grade 5: } \\
285-359\end{array}$ & $£ 22,500-£ 26,500$ \\
\hline Strength and Conditioning Coach & $\begin{array}{c}\text { Grade 6: } \\
360-469\end{array}$ & $£ 26,500-£ 33,500$ \\
\hline $\begin{array}{c}\text { Lead Strength and Conditioning } \\
\text { Coach / Performance Manager }\end{array}$ & $\begin{array}{c}\text { Grade 7: } \\
470-575\end{array}$ & $£ 40,500-£ 40,500$ \\
\hline $\begin{array}{c}\text { Head of Strength and } \\
\text { Conditioning Services / Head of } \\
\text { Performance }\end{array}$ & $\begin{array}{l}\text { Grade 8: } \\
576-640\end{array}$ & \\
\hline
\end{tabular}

Table 2. 14 key elements which reflect the values of higher education

\begin{tabular}{|l|l|}
\hline 1. Communication & 8. Teamwork and motivation \\
\hline 2. Liaison and networking & 9. Service delivery \\
\hline 3. Decision making processes and outcomes & 10. Planning and organising resources \\
\hline 4. Initiative and problem solving & 11. Analysis and research \\
\hline 5. Sensory and physical demands & 12. Work environment \\
\hline 6. Pastoral care and welfare & 13. Team development \\
\hline 7. Teaching and learning support & 14. Knowledge and experience \\
\hline
\end{tabular}

Role Analysis (HERA) framework, ${ }^{10}$ an employee should be paid in accordance with the requirements and expertise of the undertaken role. The IUSCA provides HERA gradings for S\&C coaches (Table 1) using the HERA scoring matrixes available from the Educational Competencies Consortium (ECC). ${ }^{11}$

The HERA scoring was developed by a consortium of higher education institutions to cover the vast range of jobs which can be found within the higher education sector. The scheme has been rigorously tested at a national level to ensure that it is fit for purpose. ${ }^{12}$ HERA analyses roles against 14 key elements (Table 2) which reflect the values of higher education, and the aspects of the roles identified as being the most important. All roles are analysed against the same elements.

Notably, the HERA framework uses a questionnaire format made up of 50 statements/questions to measure the level of responsibility and demands of a role in relation to each element. Once the appropriate role information has been gathered, each element is scored using the HERA scoring system. These scores are then combined to give an overall point score for the role. It is this score that determines the relative value/worth of roles, and ultimately the grade a role is assigned. The associated salaries presented in Table 1 are represent figures based on 2020 averages at our surveyed universities. ${ }^{8}$

\section{IUSCA STRENGTH AND CONDITIONING JOB DESCRIPTIONS AND PERSON SPECIFICATIONS}

To support proposed gradings and job titles presented in Table 1, the IUSCA has developed Job Descriptions and Person Specifications appropriate for university provision of S\&C in the UK.

Please see https://www.iusca.org/salary-guidelines

\section{CONCLUSION}

The purpose of this Position Statement was to standardise the role gradings and associated salary bands for S\&C coaches within UK Universities. The IUSCA recommends that these gradings should be incorporated by universities in the UK to ensure a fair and transparent valuation of the work of an S\&C coach/practitioner. This should help to standardise 
the provision within universities and gives the appropriate recognition for the S\&C professional. In turn, this will provide a basis for further analysis of remuneration in other countries and sectors within S\&C, and perhaps help guide professional sport towards similar standards and recognition.

\section{REFERENCES}

1. National Strength \& Conditioning Association. NSCA Strength and Conditioning Professional Standards and Guidelines. Strength and Conditioning Journal. 2017; 39(6): 1-24. https://journals.Iww.com/nscascj/Fulltext/2017/12000/NSCA_Strength_and_ Conditioning_Professional.1.aspx

2. Austin S. Blackpool's £12k Head of Sport Science job branded a 'disgrace' Dec 15. Available at: https://trainingground.guru/articles/blackpools-12khead-of-sport-science-job-branded-a-disgrace. Accessed 1 July, 2019.

3. Bishop CJ, McKnight P, Alexander C, Archer E, Hunwicks R, Cleather DJ. Advertising paid and unpaid job roles in sport: an updated position statement from the UK Strength and Conditioning Association. British Journal of Sports Medicine. 2019; 53(13): 789-790. https://bjsm.bmj.com/ content/bjsports/53/13/789.full.pdf

4. Bird SP, Mitchell J. Current issues affecting strength and conditioning coaches: Professional standards, coaching structures, mentorships and remuneration guidelines. Journal of Australian Strength and Conditioning. 2019; 27(5): 33-37. https://www. strengthandconditioning.org/jasc-27-5/2380-fromthe-field-directed-topic-current-issues-affectingstrength-and-conditioning-coaches-professionalstandards-coaching-structures-mentorshipsremuneration-guidelines

5. National Strength and Conditioning Association. 2018 National Strength and Conditioning Association's Coaches Survey. Oct. Available at: https://www.nsca.com/salary. Accessed April 17, 2021.

6. Bishop C. Remuneration and professional development for interns. UKSCA Intern Pack: UK Strength and Conditioning Association; 2018: 2-3.

7. Australian Strength and Conditioning Association. Guide to Remuneration Rates for ASCA Professional Coaches. May 5, 2019. Available at: https://www. strengthandconditioning.org/documents/asca-pcasremuneration-rates.pdf. Accessed April 23, 2021.

8. International Univerities Strength and Conditioning Association. Strength and conditioning coaches role and grading across universities in the United Kingdom (UK) London, UK 2020.

9. Gale D. The law of supply and demand. Mathematica Scandinavica. 1955; 3(1): 155-169. http://www.jstor.org/stable/24490348

10. University of Oxford. Information about the HERA role analysis scheme. Available at: https://hr.admin. ox.ac.uk/higher-education-role-analysis-hera. Accessed April 15, 2021.

11. Educational Competencies Consortium. ECC Role Analysis Tools - HERA and FEDRA schemes and software. Available at: http://www.ecc.ac.uk/benefitsof-ecc-membership/ecc-role-analysis-tools-heraand-fedra-schemes-and-software/. Accessed April 10, 2021.

12. University of St. Andrews. HERA Explained. Available at: https://www.st-andrews. ac.uk/hr/gradingrewardandconditions/ roleanalysisheraoverview/heraexplained/. Accessed April 15, 2021. 